\title{
Young Australians living with parents: free and pay board as popular housing tenure choices
}

\author{
Jason Chia ${ }^{1} \cdot$ Isil Erol $^{2}$ (i) \\ Received: 17 April 2020 / Accepted: 1 November 2021 / Published online: 24 November 2021 \\ (c) Crown 2021
}

\begin{abstract}
Young adults staying with parents is definitely a growing housing tenure in Australia. This paper, for the first time, unearths individual-level housing tenure choices of young Australians from the household-level data of owning/renting from the 2017 Household Income and Labour Dynamics in Australia survey. In addition to owner-occupation and private rental, the paper explores the influence of personal characteristics on two types of multigenerational co-residence: young adults who live with parents rent-free and pay board. The results show that, in Australia, young women are more independent in their housing tenure choices (i.e., owning and renting) in comparison to young men. There is a growing trend towards mature and high-earning young people living with parents for free, which might be explained by the aim of saving money to buy a house or investment property and also care arrangements for their elderly parents. Marital status has also a significant effect on housing tenure choices. Never married young adults prefer to live with parents either for free or pay board; while those divorced/separated or widowed prefer to rent privately to maintain their residential independency, after life circumstances changed. This study informs policy makers to provide more support to young adults in a fully or partly independent housing tenure (renting and paying board) in assisting them to climb up the housing career ladderbecoming a homeowner.
\end{abstract}

Keywords Australia $\cdot$ Housing tenure $\cdot$ Living with parents $\cdot$ Multinomial logistic regression $\cdot$ Pay board $\cdot$ Young adults

\section{Introduction}

Home ownership has fallen since the early 2000s and became more prominent after the 2008/09 financial crisis (Arundel \& Doling, 2017; Lennartz et al., 2016). Young adults are increasingly pushed into the private rental sector (Fuster et al., 2019; Hoolachan et al.,

Isil Erol

i.erol@henley.reading.ac.uk

1 School of Economics and Finance, Sessional Academic, Queensland University of Technology,

Property Economics, Brisbane, Australia

2 Department of Real Estate \& Planning, Henley Business School, Whiteknights Campus, University of Reading, Reading RG6 6UD, UK 
2017; Ronald, 2018) and multigenerational co-residence arrangement (Aassve et al., 2013; Coulter, 2018; Filandri \& Bertolini, 2016; Lennartz, et al., 2016; Mykyta \& Macartney, 2011; Tosi \& Grundy, 2018). To reflect the delay in home-leaving or re-entry to the parental home, creative phrases such as generation rent $^{1}$ (Hoolachan, et al., 2017; McKee, 2012), boomerang kids (Kaplan, 2009), parasite children, and yo-yo transitions (Forrest \& Yip, 2012) are used to illustrate the different residential trajectories of young people (Arundel \& Doling, 2017; Arundel \& Lennartz, 2017; Arundel \& Ronald, 2016).

In Australia, the home ownership rates have not declined greatly over the last fifty years, but the decline is apparent among the younger households (Hall, 2017). The Household Income and Labour Dynamics in Australia (HILDA) survey showed that the home ownership for households with a reference person aged 25-34 years had declined significantly from $52.2 \%$ in 1996 to $29.2 \%$ in 2014. Australia has experienced a severe housing affordability crisis as the country climbed from $29^{\text {th }}$ to the $9^{\text {th }}$ most unaffordable country for housing among the OECD (Organisation for Economic Co-operation and Development) countries between year 2010 and 2014. The decline in affordability, coupled with the reduction in welfare entitlement, directly impinged on their housing career ladder to independence (Colic-Peisker \& Johnson, 2012). The evident decline in home ownership of the young people is also an outcome of the changing nature in lifestyle choices (Mudd et al., 2001; Ronald, 2018) and the reordering of life priorities (Bessant \& Johnson, 2013; Settersten, 2007). Young adults are choosing to stay single till later stage of their life, travelling, deferring parenthood or being child-free indefinitely (Bessant \& Johnson, 2013).

This paper uses the 2017 HILDA survey to derive individual-level data on housing tenure choices of all household members from the 9,200 households. The four different tenure types are owner-occupation, private rental, living with parents (pay board), and living with parents for free. Hence, this study extends on the residential trajectories of young people by exploring two types of multigenerational co-residence, namely, young adults who live with parents (or extended family member)rent-free and pay board. Whilst the first group are completely dependent individuals, the latter can be defined as partly independent individuals in their residential pathways. It is parents' personal decision whether to charge board, while most parents believe that paying board enhances their child's independence and financial responsibility (Reilly, 2017).

The present study contributes to the current knowledge on the housing tenure experiences of young adults in several ways. First, the paper defines young adults within the Australian context based on the country's tax and social security system, private health insurance coverage, and the rules of owning and renting a property. Second, this study, for the first time, unearths individual-level housing tenure choices of young adults from the household-level data of owning/renting from the HILDA survey. Although a considerable amount of research has been conducted on young Australians and their housing tenure choices by employing household level data, only few studies so far have investigated the housing pathways of young Australians by using individual-level data. Beer and Faulkner (2009) used Australian Housing and Urban Research Institute survey data; McDonald and Baxter (2005) employed Negotiating the Life Course Survey data; and lately Parkinson, et al. (2019) used the Australian Housing Aspirations survey to study housing pathways and aspirations of young Australians. Unlike the previous research, the present study uses HILDA survey that collects information on many aspects of life in Australia and conducts

1 Generation rent refers to renting a dwelling as a long-term tenure. 
a thorough analysis of housing tenure choices of all individuals covered in the survey dataset, not just those designated as household reference persons. Third, this paper explores a growing, novel type of housing tenure among young population: living with parents and pay board, in addition to owning, renting a house or living with parents for free.

Almost 32\% of young Australians aged 16-34 live with parents in 2017; while 27.9\% live in parental home for free, the remaining $4.1 \%$ pay board. Our results indicate that socio-demographic characteristics - e.g., age, gender, income level, and employment status-strongly affect young Australians' housing tenure choices. The most notable findings of this study are: (1) Non-marriage (or late marriage) among young Australians increases the probability of living with parents. Never married young adults who previously have not experienced independent living prefer to live with parents either for free or pay board; while the divorced/separated or widowed young adults who have already experienced their residential independency have a preference to maintain it by renting privately; (2) Mature young adults (30-34-year-olds) with high-income have unpredictably a higher likelihood to live with parents for free. Their motivation for co-residing with parents may possibly be explained by the aim of saving money to buy a house or investment property and also care arrangements for their children or elderly parents; (3) Young adults, especially 16-29-yearolds, in vocational education are partly independent and highly likely to pay board while living with parents. Those studying in senior high school or university degrees, in contrast, have a lower probability to pay board and a higher probability of co-residing with parents for free.

The rest of the paper is organized as follows. Sect. 2 reviews existing research on the rising trend of young people living with parents and the housing tenure choices of young Australians. Section 3 defines young adults in the Australian context and provides a brief discussion on obtaining individual-level data from the household-level HILDA survey. Section 4 presents descriptive data analysis, and Sect. 5 provides the results of multinomial logistic regression analysis. Section 6 concludes the paper.

\section{Literature review}

\subsection{Young adults living with parents}

Leaving the parental home marks the transition to adulthood, which at the same time has become increasingly hard to attain in many countries (Druta \& Ronald, 2018). The current trend of young adults living with their parents is a topic of continual discussion, especially in the USA, Canada and the European countries. However, related research on the Australian experience has been limited compared with these countries.

Existing literature on the young adults' housing tenure choices can be broadly classified into three groups. The first group examines the timing and factors of leaving and returning to the parental home. There are individual characteristics such as parental household composition (Goldscheider \& DaVanzo, 1985), socio-economic status (Holdsworth, 2004; Le Blanc \& Wolff, 2006), demographic indicators such as age and gender (Billari \& Liefbroer, 2007; Goldscheider \& DaVanzo, 1985), rising debt levels (Andrew, 2010; Dettling \& Hsu, 2018; Houle \& Warner, 2017) and peer group effects (Adamopoulou \& Kaya, 2018). The second strand of literature studies the intergenerational co-residence (Aranda, 2015; Russell \& Taylor, 2009; Silverstein et al., 2006). A recent study by Tosi and Grundy (2018) 
examines the return of adult children to the parental home for 17 European countries, and finds that generally, parents experienced a decline in quality of life.

The third group focuses on different scenarios that could potentially influence the young people's home ownership, as follows.

The socio-economic of family background and parental attributes (Bayrakdar et al., 2019; Coulter, 2018; Filandri \& Bertolini, 2016; Heath \& Calvert, 2013; Mulder et al., 2015; Öst, 2012).

Life-course events, such as completing education, delayed marriage or family formation, long-term partnership and childbirth (Bayrakdar, et al., 2019; Berngruber, 2015; Filandri \& Bertolini, 2016; Fisher \& Gervais, 2011; Forrest \& Yip, 2012; Mulder \& Billari, 2010; Mulder, et al., 2015).

Intergenerational support in terms of financial assistance (Choi et al., 2018; Coulter et al., 2016; Druta \& Ronald, 2018; Filandri \& Bertolini, 2016; Heath \& Calvert, 2013; Helderman \& Mulder, 2007; Lennartz, et al., 2016; Ronald, 2018).

The role of housing systems under the neoliberal policy regimes (Boterman \& Van Gent, 2014; Druta \& Ronald, 2018; Forrest \& Yip, 2012; Hoolachan, et al., 2017).

Similarities in housing market circumstances of parents, such as distance to parents' house (Cooper \& Luengo-Prado, 2018; Helderman \& Mulder, 2007; Henretta, 1987; Mulder \& Wagner, 2001; Mulder, et al., 2015).

The 2008/09 financial crisis and its effects on housing markets (Aassve, et al., 2013; Arundel \& Doling, 2017; Arundel \& Ronald, 2016; Fuster, et al., 2019; Helderman \& Mulder, 2007; Lennartz, et al., 2016).

\subsection{Housing tenure choices and aspiration of young Australians}

The 'Australian dream', which is to achieve home ownership, was generally attainable a decade ago (Colic-Peisker \& Johnson, 2010). Today, it is believed that the great Australian dream is still alive in the Australians, but renters and those hovering between owning and renting have been rising (Lane, 2019). Recent research by Daley and Coates (2018) shows that home ownership rates in Australia are now decreasing among all age groups except for those over 65 years old, and it is most prominent among the young and low-income earners. A considerable number of studies have examined aspects of falling home ownership rates among the young Australians (Hughes, 1996; Mudd, et al., 2001; Percival, 1998; Winter \& Stone, 1998; Yates, 2000), which could possibly be an affordability issue (Yates, 1999, 2003), or the delay in family formation among young Australians (Mudd, et al., 2001). Yates (1999) indicated that decline in home ownership was associated with low income and mostly seen in young couples with children. Furthermore, Yates (2003) showed that the decrease in home ownership rates among young Australians was mainly due to large increases in house prices, especially in larger cities. Lately, Cigdem and Whelan (2017) found that intergenerational transfers, such as inheritances and gifts, increased the probability of young adults in Australia to climb up the housing career ladder. Another important factor that tends to be positively associated with home ownership is the tertiary education and vocational training. Andrews and Sanchez (2011) found that household heads with tertiary education are more likely to be a homeowner than those without post-secondary education in the UK; however, there 
is a much smaller impact of tertiary education and associate-level (e.g., trade) qualifications in Australia on the probability to be a homeowner. ${ }^{2}$

Mudd, et al. (2001) argued that the decline in home ownership was purely reflecting a change in lifestyle and preference among the young adults. McDonald and Baxter (2005) found that the decrease in home ownership rates at young ages were mainly because of the delay in family formation. The increasing job-to-job mobility and earning uncertainty does not boost the financial stability to own a permanent place of residence (Beck \& Beck-Gernsheim, 2002; Fisher \& Gervais, 2011; Reich, 2008). Bessant and Johnson (2013) highlighted the social change such as staying single, being child-free indefinitely or spending the early years travelling (Hamilton, 2008; Mudd, et al., 2001; Rodrigues, 2003). Young Australians have also delayed leaving their parents to live rent-free (Wood \& Ong, 2017). Flatau et al. (2003) discovered that the spending longer time to pursue higher education enhanced the delay to leave their parents' home. Shared living in a group household or intergenerational home (moving back to their parents) have been seen as short-term solutions to combat housing affordability issues in staying closer to their education and/or employment.

As much as home ownership gives people's positive perceptions of identity and status, it may also create its own set of anxiety, such as mortgage indebtedness and the housing market volatility (Colic-Peisker \& Johnson, 2010). Despite the current situations, some researchers claimed that the Australian dream on home ownership is still alive. In comparison to other housing tenures (i.e., private and public renting), home ownership portrays stability and status (Colic-Peisker \& Johnson, 2012; Parkinson et al., 2019).

An up to date research funded by the Australian Housing and Urban Research Institute (AHURI) focused on housing policies to assist young adults to meet their short and long term housing aspirations (Parkinson, et al., 2019). The research findings revealed that more than half of the 2,477 young adults who filled the Australian Housing Aspiration (AHA) survey aspired to live in a house (68\% of 1,566 people aged $25-34 ; 54 \%$ of 911 people aged between 18 to 24 years). The four main housing aspirations of these young people were: (i) to pursue and live near opportunities for study and work, (ii) to balance flexibility with security within the dwelling and community, (iii) to provide diversity and real choice in the dwelling and location, and (iv) to move towards independence and longerterm financial freedom and security.

A considerable amount of research was conducted to investigate the housing tenure choices of young people from the household-level. They used data sources such as ABS Census, the ABS Survey of Income and Housing (SIH), Australian Housing Survey (AHS), and HILDA survey (Burke et al., 2007; Cigdem \& Whelan, 2017; Mudd, et al., 2001; Wood \& Ong, 2017; Yates, 2003). Only a few studies performed analysis at individual-level data on housing tenure decisions. For example, McDonald and Baxter (2005) used individual-level data on home ownership based on the Negotiating the Life Course Survey, which was conducted in 1997, repeated every 3 years in 2000, 2003, 2006 and last conducted in 2010. Parkinson, et al. (2019) employed individual-level data on housing aspirations using Australian Housing Aspirations (AHA) survey. Similarly, Beer and Faulkner (2009) conducted the 'Housing 21' research project from AHURI survey data. To build upon the existing knowledge of young people's housing consumption behaviour, this

\footnotetext{
2 Andrews \& Sanchez (2011) pointed out that the impact of tertiary education on home ownership is not always statistically significant - possibly due to the high correlation with household income in Austria, Spain and Switzerland.
} 
study attempts to unearth individual-level data from the household-level HILDA survey and carries out a thorough analysis of housing tenure choices of all individuals covered in the survey dataset, not just those designated as household reference persons.

Several approaches have been developed to study housing consumption behaviour of households and/or individuals, starting from the consumer behaviour theory. These theoretical approaches to housing tenure decisions are, namely, the neoclassical economic theory of consumer behaviour (Arnott, 1997; Hubert, 2007), the socio-demographic approach (i.e., Goodman, 1990; Meen, 1998), the structural approach, and the behavioural economics approach (i.e., Morris \& Winter, 1978; Case \& Shiller, 1998). In order to investigate housing careers of young people in Australia, this study employs the socio-demographic approach, which considers the impacts of individual's socio-demographic characteristics and preferences in relation to housing consumption rather than the economic determinants of housing consumption behaviour such as house price, cost and financial gain of homeownership, and housing supply; the underlying macroeconomic, political, legal, and geographical factors; and the behavioural and psychological factors influencing housing tenure decisions.

\section{Unearthing the individual-level housing tenure choices of young Australians from household-level HILDA survey}

In Australia, data on housing tenure choices of the people can be derived from three sources: the ABS Census of Population and Housing, the ABS Survey of Income and Housing (SIH), and the Household Income and Labour Dynamics in Australia (HILDA) survey. The ABS census is collected on a 5-yearly cycle, the SIH runs every 2 years, and the HILDA Survey runs annually. The conventional analysis of housing tenure choices is based on census data from a household perspective. McDonald and Baxter (2005) highlighted that the conventional approach of using household-level data can be misleading, especially when the aim is to examine the tenure choices of young people. For instance, staying with parents among the young people would go unobserved. Specifically, if the tenure type of a dwelling is 'owned', when linked with individual data, every individual staying in that dwelling will have 'owned' as the tenure type or will be homeowner. Generally, a safer assumption is to associate the dwelling tenure type with the household reference person (Yates, 2003), but 15-24 years old Australians are usually not the household reference person (McDonald, 2003).

The present study uses 2017 HILDA survey. ${ }^{3}$ HILDA is a household-based study that collects social-economic and demographic data of 23,415 people from 9,742 households. Every individual in HILDA Survey has a unique identifier, and individuals in the same household have the same household identifier. This enables data from the 'Household Form' to be translated to every individual in all corresponding households by using the same household identifier. The imputed variables in the 'Household' file relate to everyone in-scope in responding households, including interviewed adults, non-interviewed adults and non-interviewed children. The following question of the survey identifies the household-level housing tenure choice: 'Do you (or any other members of this household) own

\footnotetext{
3 The 2017-2018 SIH data are also available; however, due to the structure and limitation of dataset it was not possible to unearth the individual level tenure types from the survey.
} 


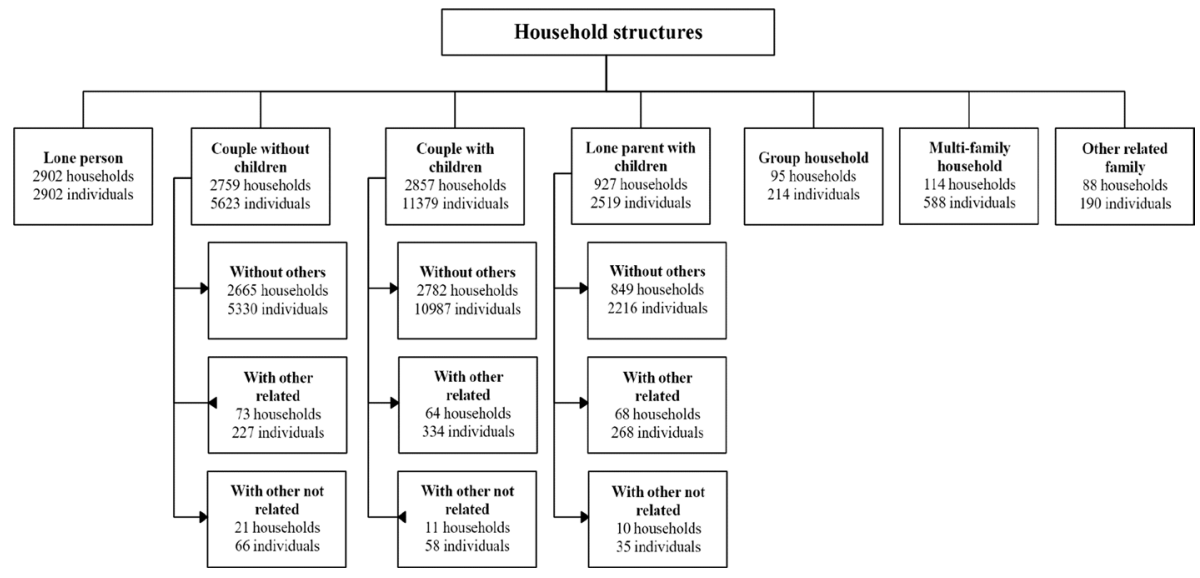

Fig. 1 Main household structures

this home, rent it, or do you live here rent-free?' There are four possible answers to this question, in addition to 'refuse to answer' and 'don't know' responses: (1) Own, (2) rent (or pay board), (3) involved in a rent-buy scheme, and (4) live under a life tenure scheme. Owning a house includes either purchasing the property outright or paying off mortgage. According to the Social Security Act subsection 13(1) of the Australian Government, 'board' is defined as the provision of meals and accommodation. In Australia, some parents ask their child to pay board to build up their independence and financial responsibility. Whilst rent-buy scheme refers to the partial owning of a property and paying rent for the remainder, life tenure scheme is a common arrangement especially in retirement villages where households do not possess the equity.

The household structures and the corresponding numbers of households and individuals in each household type across the sample data are displayed in Fig. 1. Multi-family and other related family households are excluded from the data analysis as it is too complicated to differentiate the real owner or renter of the dwelling. Similarly, there is not a clear definition of other related family household, for which the number of observations is very small —only $0.84 \%$ of the total number of people surveyed. The present study uses lone person household, lone parent with children, couples with/without children and group households in order to define housing tenure types at the household level. After eliminating the multi-family and other related family households, the study sample consists of 9,540 households and 22,637 individuals.

As seen in Fig. 1, almost one in three household (30.42\% of 9,540 households) is a loneperson household in 2017. Amongst the family households, the couple family with children and couple family without children have $29.95 \%$ and $28.92 \%$ shares in the total number of households, respectively. The high percentage of couples without children would possibly reflect the ageing population (Australian Bureau of Statistics, 2010).

As expected, owning and renting are two main housing tenure choices at the household level (see Table 1). The percentage of owning and renting a house is distributed fairly among the lone person/lone parent with children households. Specifically, $45.73 \%$ of lone person households own their dwellings, while $48.00 \%$ stay in rental properties. As for lone parent with child household, $44.23 \%$ of them own the property, while $52.86 \%$ of them living in rental properties. $5.79 \%$ of lone person households have a life-tenure contract, and 
Table 1 Housing tenure choices of Australians at the household level

\begin{tabular}{llllll}
\hline Household structure & \multicolumn{4}{l}{ Housing tenure (percentage) } \\
\cline { 2 - 6 } & Own & Rent & $\begin{array}{l}\text { Rent-free/ } \\
\text { life- tenure }\end{array}$ & Rent-buy scheme & Total $^{*}$ \\
\hline Lone person household & 45.73 & 48.00 & 5.79 & 0.03 & 100.00 \\
Lone parent with child household & 44.23 & 52.86 & 2.70 & 0.00 & 100.00 \\
Couple without child household & 71.73 & 25.55 & 2.54 & 0.07 & 100.00 \\
Couple with child household & 73.08 & 25.06 & 1.51 & 0.07 & 100.00 \\
Group household & 24.21 & 72.63 & 3.16 & 0.00 & 100.00 \\
\hline
\end{tabular}

*The responses of "refuse to answer" and "don't know" are not displayed as these groups have negligible shares in total responses; which is $0.10-0.28 \%$ for couple households, and $0.22-0.45 \%$ for lone parents with children and lone person household, respectively

possibly these are senior people living in retirement communities. Couple families dominantly own their houses (71.73\% to $73.08 \%$ ) and only one fourth of all couple households rent their dwellings. Approximately $73.08 \%$ of group households rent their houses, whilst $24.21 \%$ own and the remaining $3.16 \%$ has a life-tenure contract.

This study excludes the housing tenure type of rent-buy scheme due to its small representation of tenure choice and the life tenure scheme as it is a common arrangement for senior population. The study also eliminates observations with 'refuse to answer' and 'don't know' as responses. Hence, our study only employs 9,200 households (22,008 people) in order to derive the individual-level housing tenure choices of young adults in Australia. They are the owners (either own outright or currently paying off mortgage), and renters.

\subsection{Defining the young adults}

In this study, young adults in Australia are defined as those aged between 16 and 34 years old. They are independent adults who can make their own decisions in choosing their own housing tenure.

Table 2 lists the different age thresholds that are used to define young adults both in the existing research on housing tenure and in the Australian context through the tax and social security system, private health insurance coverage, and the rules of owning/renting a property. All children are dependent to their parents if they are within the compulsory education age for primary and secondary school which is between the ages of 6 and 16 (Commonwealth of Australia, 2019). In Australia, young people have more opportunities such as working part/full time and renting a house/an apartment to be independent from the age of 16. In the legal context, they will only be considered as an adult when they turned 18 years old. There are exceptions depending on their occupation (e.g., full time students) and marital status. Australian private health insurance and tax system acknowledge a person as dependent until 24 years old if they study full time. 25 years old, regardless of occupation and marital status, is the final threshold in defining adulthood.

Figure 2 illustrates the process to identify young adults' tenure choices by using household-level data. The flowchart explains the rules of unearthing the young adults' housing tenure choices - owning, renting, paying board, and rent-free living. 


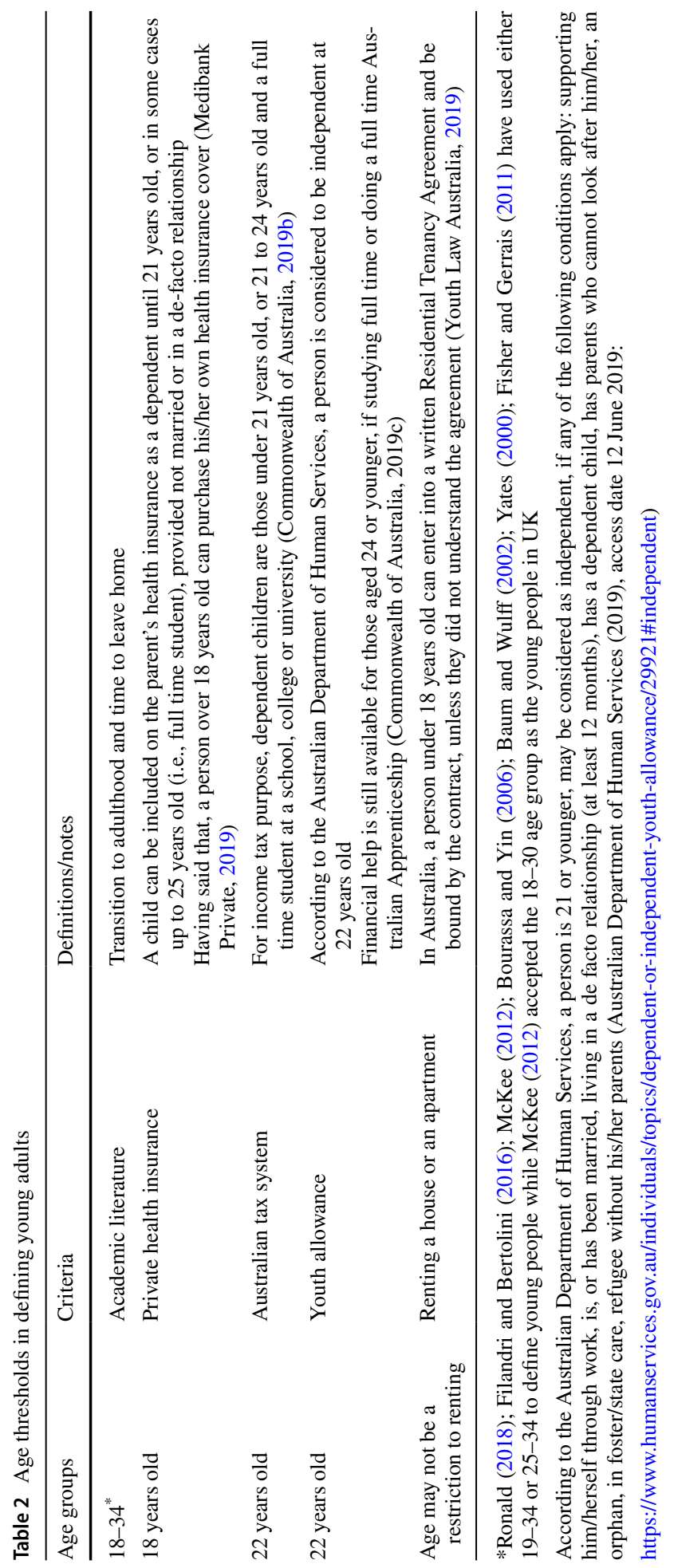




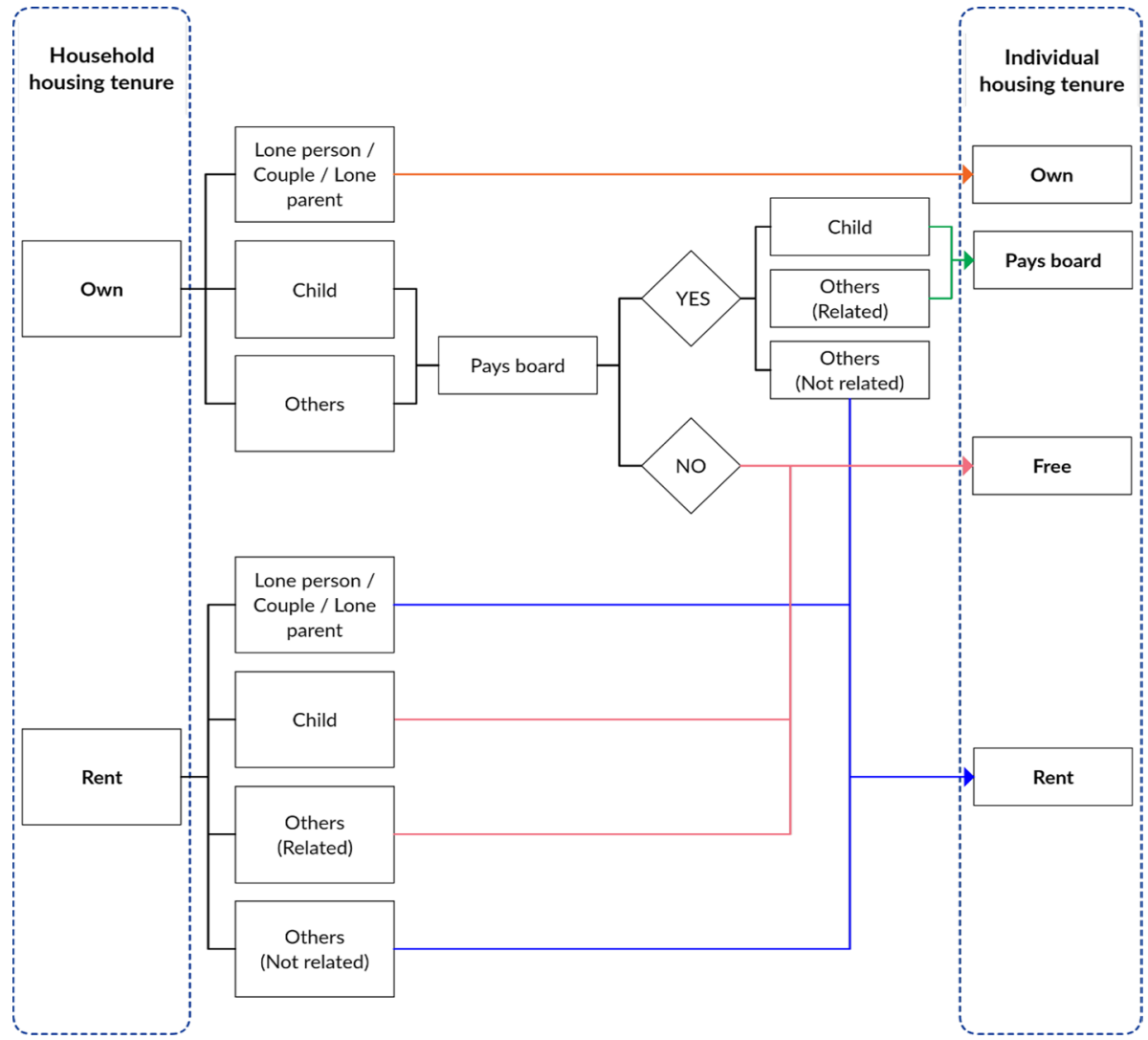

Fig. 2 Unearth the individual-level housing tenure choices of young Australians from the household-level housing tenure choices

If the household's tenure choice is 'owner-occupation' and the household type is lone person, then that person will be the 'owner'.

If the household's tenure choice is 'owner-occupation' and the household type is couple/ lone parent, then both of the couple and the lone parent will be the owner, while their child /other related either 'pays board or lives free'. If, other not related pay board, he/she will be recorded as 'renter'. 4

If the household's tenure choice is 'rent', only the lone person/the couple/lone parent will rent the dwelling, while their child/other related lives free and other not related will be recorded as a 'renter'. 5

Finally, for the group household, all individuals are accepted as 'others not related' and there is no household-head.

\footnotetext{
4 'Other related individuals in the household' refers to members of the extended family. Others not related are the individuals who are not from the household of origin.

${ }^{5}$ Pay board mechanism only works for owner households, that is, the question of 'paying board' is only asked if the household tenure type is 'owned', not for renter households.
} 
Table 3 Individual-level analysis for the housing tenures choices of young adults

\begin{tabular}{|c|c|c|c|c|c|c|}
\hline \multirow[t]{2}{*}{ Age groups } & \multirow{2}{*}{$\begin{array}{l}\text { Age groups in } \\
\text { overall sample } \\
(\%)\end{array}$} & \multicolumn{5}{|c|}{ Housing tenure choices $(\%)$} \\
\hline & & Own & Rent & Pay board & Free living & Total \\
\hline 16-21 Early young adulthood & 27.66 & 1.55 & 22.30 & 5.95 & 70.20 & 100.00 \\
\hline 22-29 Middle young adulthood & 43.80 & 22.87 & 55.50 & 4.78 & 16.85 & 100.00 \\
\hline 30-34 Mature young adulthood & 28.54 & 49.57 & 45.51 & 1.11 & 3.80 & 100.00 \\
\hline 16-34 All young adults & 100.00 & 24.59 & 43.47 & 4.06 & 27.88 & 100.00 \\
\hline
\end{tabular}

After identifying the owner or renter in a household, the next step is to determine if other member pays board or live under rent-free condition.

\section{Descriptive data analysis}

The present study defines individuals aged 16 and 34 years old as the young adults, and further defines three age-subgroups in order to perform a detailed analysis of young adults' housing tenure choices: early young adulthood (aged 16-21 years old); middle young adulthood (aged 22-29 years old); and mature or late young adulthood (aged 30-34 years old).

Table 3 shows that $43.47 \%$ of young adults in Australia rent their dwellings and $27.88 \%$ live with their parents under rent-free condition. Homeowners consist of $24.59 \%$ of all tenures and $4.06 \%$ of young adults pay board while living with their parents. Almost onethird (31.94\%) of all young adults are co-residing with their parents, either in a rent-free arrangement or pay board.

In the early years of young adulthood, young people mainly live with parents for free (70.20\%), and as age progresses, they prefer to rent a place-e.g., 55.50\% of those aged 22-29 years old rent a dwelling - and later as they become a mature young adult, almost half of them (49.57\%) prefer to own their house. It is observed that partly independent young adults who live with parents and pay board are predominantly in their early-to-middle years of young adulthood; aged between 16 and 29 years. Among the mature young adults, only $1.11 \%$ pay board but $3.80 \%$ of them live with parents for free as dependent young people.

Table 4 shows the descriptive analysis of different young adults' personal attributes, such as gender, marital status, employment, annual income, current education status, and the country of birth, in respective to different age sub-group and housing tenure in percentage, while Table 5 shows the absolute count.

Considering the gender effect on young adults' housing tenure choices, it is observed that young women in Australia own or rent their dwelling at a higher ratio in comparison to men. More young men live with their parents for free as compared with the women in each age sub-group. Specifically, for young adults aged between 16 and 34 years, $30.53 \%$ of men and $25.42 \%$ of women live with parents under rent-free condition. Only 5.04\% of men and $3.14 \%$ of women pay board. Women have a higher ratio of owner-occupation $(26.76 \%)$ in comparison to males (22.27\%). In the middle years of young adulthood, $26.15 \%$ of men live with parents and either pay board (6.15\%) or under rent-free condition $(20.00 \%)$. On the contrary, only $17.59 \%$ of women prefer co-residence with their parents. Hence, female 


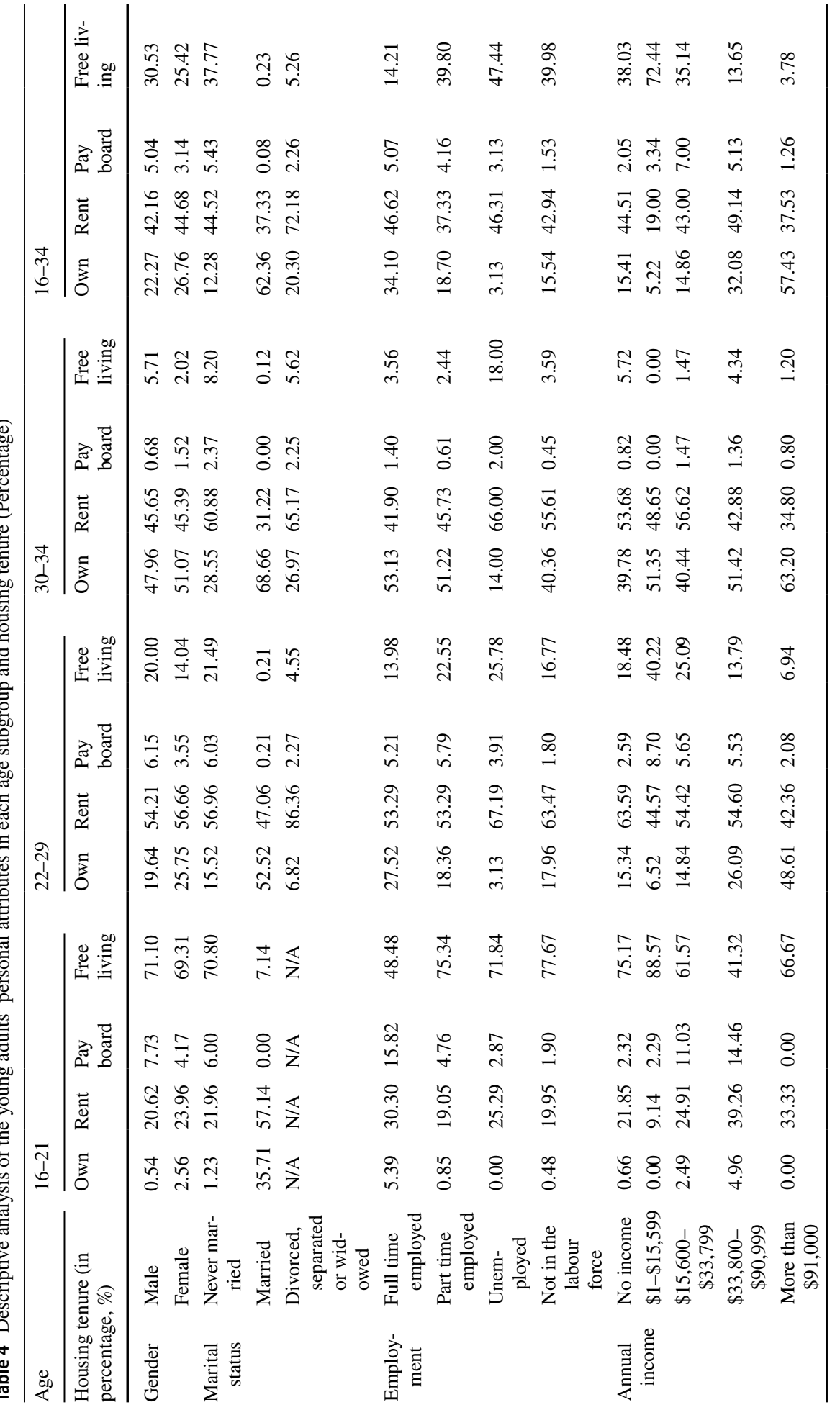




\begin{tabular}{|c|c|c|c|c|c|c|c|c|c|c|c|c|}
\hline & 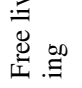 & $\stackrel{m}{\stackrel{n}{a}}$ & 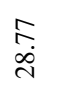 & $\begin{array}{l}\text { f } \\
\text { in }\end{array}$ & $\begin{array}{l}\stackrel{9}{\leftrightarrows} \\
\stackrel{-}{-}\end{array}$ & $\begin{array}{l}\underset{\infty}{+} \\
\dot{J}\end{array}$ & $\begin{array}{l}\stackrel{0}{1} \\
\text { İ } \\
\text { f }\end{array}$ & $\stackrel{0}{0}$ & 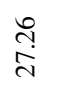 & $\begin{array}{l}\text { : } \\
\text { ते in }\end{array}$ & & $\stackrel{5}{\underline{0}}$ \\
\hline & 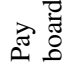 & $\stackrel{5}{0}$ & $\stackrel{+}{0}$ & $\bar{n}$ & $n$ & $\begin{array}{l}\infty \\
\infty \\
\infty\end{array}$ & $\begin{array}{l}\tilde{b} \\
\dot{n}\end{array}$ & ڤn? & ฟै & $\underset{f}{f}$ & & $\underset{-}{\stackrel{J}{*}}$ \\
\hline & 节 & $\underset{i}{8}$ & $\stackrel{\infty}{\stackrel{\infty}{r}}$ & $\begin{array}{l}\infty \\
\infty \\
\stackrel{n}{n}\end{array}$ & $\begin{array}{l}\text { aे } \\
\text { î }\end{array}$ & 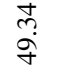 & 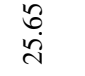 & 尺े & $\stackrel{m}{8}$ & 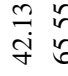 & & $\frac{\mathfrak{a}}{\mathfrak{g}}$ \\
\hline $\begin{array}{l}\text { के } \\
\underline{b}\end{array}$ & है & $\stackrel{8}{\circ}$ & 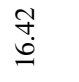 & $\stackrel{m}{\infty}$ & $\begin{array}{l}\text { ָै } \\
\text { in }\end{array}$ & $\frac{a}{\dot{m}}$ & $\begin{array}{l}\text { ते } \\
\text { రి }\end{array}$ & $\frac{a}{a}$ & $\underset{\infty}{\stackrel{\infty}{o}}$ & $\begin{array}{l}+⿱ 亠 ⿻ ⿰ 丿 亅 八 阝 ~ \\
\dot{\lambda}\end{array}$ & & 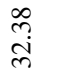 \\
\hline & 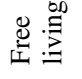 & $\overleftrightarrow{\mathrm{z}}$ & $\stackrel{゚}{\stackrel{0}{+}}$ & $\tilde{n}$ & $\stackrel{8}{0}$ & ஓे & $\stackrel{+}{\stackrel{+}{+}}$ & $\stackrel{n}{1}$ & $\tilde{i}$ & $\underset{F}{F}:$ & & $\begin{array}{l}\infty \\
n \\
n\end{array}$ \\
\hline & పే & $\overleftrightarrow{\measuredangle}$ & $\underset{i}{\stackrel{\Xi}{d}}$ & $\stackrel{m}{\sim}$ & $\stackrel{8}{0}$ & $\underset{-}{\vec{\sigma}}$ & $\stackrel{\oplus}{-}$ & ֶ̃ & $\stackrel{ \pm}{\stackrel{ \pm}{\leftrightarrows}}$ & 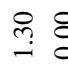 & & f̊. \\
\hline & 节 & $\overleftrightarrow{\measuredangle}$ & $\begin{array}{l}\stackrel{T}{+} \\
\stackrel{+}{n}\end{array}$ & $\begin{array}{l}+ \\
\infty \\
\infty \\
+ \\
+\end{array}$ & $\stackrel{n}{n}$ & $\begin{array}{l}\tilde{o} \\
\dot{j}\end{array}$ & $\begin{array}{l}\stackrel{8}{8} \\
\stackrel{0}{0}\end{array}$ & 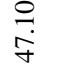 & 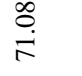 & 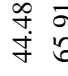 & & $\begin{array}{l}\vec{\sigma} \\
\dot{\gamma}\end{array}$ \\
\hline 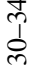 & है & $\overleftrightarrow{\mathrm{z}}$ & $\underset{\substack{\infty \\
\infty}}{\stackrel{\infty}{\infty}}$ & $\begin{array}{l}\vec{n} \\
\tilde{o} \\
q\end{array}$ & $\begin{array}{l}\text { f̊ } \\
\dot{f}\end{array}$ & $\frac{n}{n}$ & $\begin{array}{l}\text { के } \\
\text { in }\end{array}$ & ले & $\stackrel{n}{\stackrel{n}{\sim}}$ & $\begin{array}{ll}\vec{\infty} & n \\
0 & 0 \\
i & 0\end{array}$ & & 훔 \\
\hline & 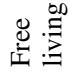 & $\overleftrightarrow{\nwarrow}$ & $\begin{array}{l}\underset{J}{J} \\
\infty \\
-0\end{array}$ & $\begin{array}{l}\hat{6} \\
\ddot{n}\end{array}$ & $\begin{array}{l}\text { సે } \\
\text { }\end{array}$ & 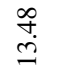 & $\overrightarrow{\dot{m}}$ & 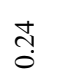 & $\begin{array}{l}\stackrel{ \pm}{ \pm} \\
\stackrel{+}{ \pm}\end{array}$ & 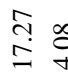 & & $\frac{\infty}{0}$ \\
\hline & తే & $\overleftrightarrow{\nwarrow}$ & $\stackrel{\infty}{\infty}$ & $\stackrel{\infty}{\stackrel{+}{+}}$ & $\begin{array}{l}0 \\
\stackrel{0}{0} \\
0\end{array}$ & $\stackrel{n}{+}$ & $\underset{\infty}{\infty}$ & $\tilde{n}$ & $\underset{\dot{b}}{\vec{b}}$ & $\underset{m}{\dot{m}}$ & & ते \\
\hline & $\begin{array}{l}\overrightarrow{0} \\
\simeq\end{array}$ & $\overleftrightarrow{\mathrm{Z}}$ & $\begin{array}{l}\infty \\
i n \\
i n\end{array}$ & $\begin{array}{l}\text { f. } \\
\text { g. }\end{array}$ & $\begin{array}{l}\infty \\
\infty \\
i \\
i n\end{array}$ & $\begin{array}{l}\text { స్ } \\
\text { in } \\
\text { in }\end{array}$ & $\vec{m}$ & ஓे & $\stackrel{\infty}{\stackrel{\infty}{\pi}}$ & 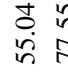 & & $\begin{array}{l}\text { ô. } \\
\text { in }\end{array}$ \\
\hline $\begin{array}{l}\text { ते } \\
\text { ते }\end{array}$ & है & $\overleftrightarrow{\mathrm{z}}$ & $\begin{array}{l}\stackrel{2}{2} \\
\stackrel{2}{2}\end{array}$ & $\stackrel{2}{\circ}$ & 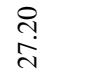 & 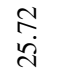 & 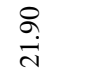 & $\begin{array}{l}\text { aे } \\
\stackrel{d}{n}\end{array}$ & 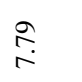 & $\begin{array}{l}\stackrel{0}{n} \\
\text { ה̇ }\end{array}$ & & $\overrightarrow{\widetilde{d}}$ \\
\hline & 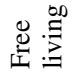 & $\stackrel{m}{\stackrel{n}{a}}$ & $\frac{7}{\circ}$ & 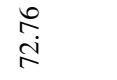 & $\stackrel{m}{m}$ & $\stackrel{\hat{a}}{\dot{\sigma}}$ & $\begin{array}{l}\stackrel{0}{1} \\
\infty \\
\infty\end{array}$ & $\underset{+}{\stackrel{8}{+}}$ & $\begin{array}{l}\infty \\
\stackrel{0}{0} \\
\text { in }\end{array}$ & $\begin{array}{l}\stackrel{c}{0} \\
\stackrel{8}{i}\end{array}$ & & 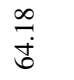 \\
\hline & 票 & $\stackrel{5}{6}$ & $\begin{array}{l}\stackrel{\infty}{ } \\
\dot{\Xi}\end{array}$ & $\stackrel{\infty}{i}$ & $\stackrel{8}{0}$ & $\ddot{\sigma}$ & ڤ̊ & $\underset{i}{i}$ & $\underset{i}{\Delta}$ & mె & & $\stackrel{8}{\circ}$ \\
\hline & 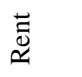 & $\underset{i}{\stackrel{8}{ }}$ & \begin{tabular}{l}
8 \\
\multirow{2}{a}{} \\
\end{tabular} & $\begin{array}{l}\tilde{N} \\
\text { } \\
\end{array}$ & $\stackrel{8}{8}$ & ঃ & $\underset{\dot{\sigma}}{\stackrel{g}{*}}$ & $\begin{array}{l}8 \\
\stackrel{\infty}{\infty}\end{array}$ & $\underset{m}{\stackrel{8}{m}}$ & 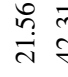 & & 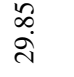 \\
\hline $\begin{array}{l}\vec{\tau} \\
\underline{b}\end{array}$ & है & $\stackrel{8}{0}$ & $\stackrel{\infty}{\stackrel{\infty}{i}}$ & $\stackrel{n}{n}$ & $\underset{\sigma}{\sigma}$ & $\frac{n}{i}$ & $\stackrel{\overbrace{}}{0}$ & $\stackrel{m}{m}$ & กิ & $\hat{m}$ & & $\hat{a}$ \\
\hline$\stackrel{8}{\&}$ & 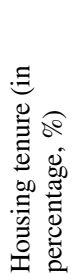 & 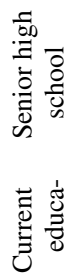 & 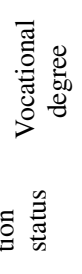 & 离 & 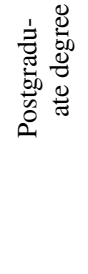 & 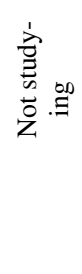 & 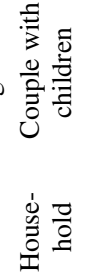 & 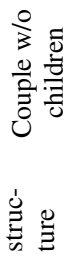 & 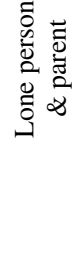 & 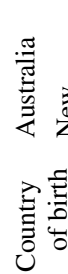 & 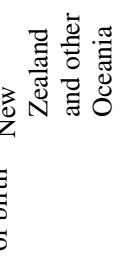 & 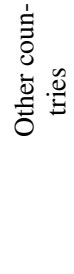 \\
\hline
\end{tabular}




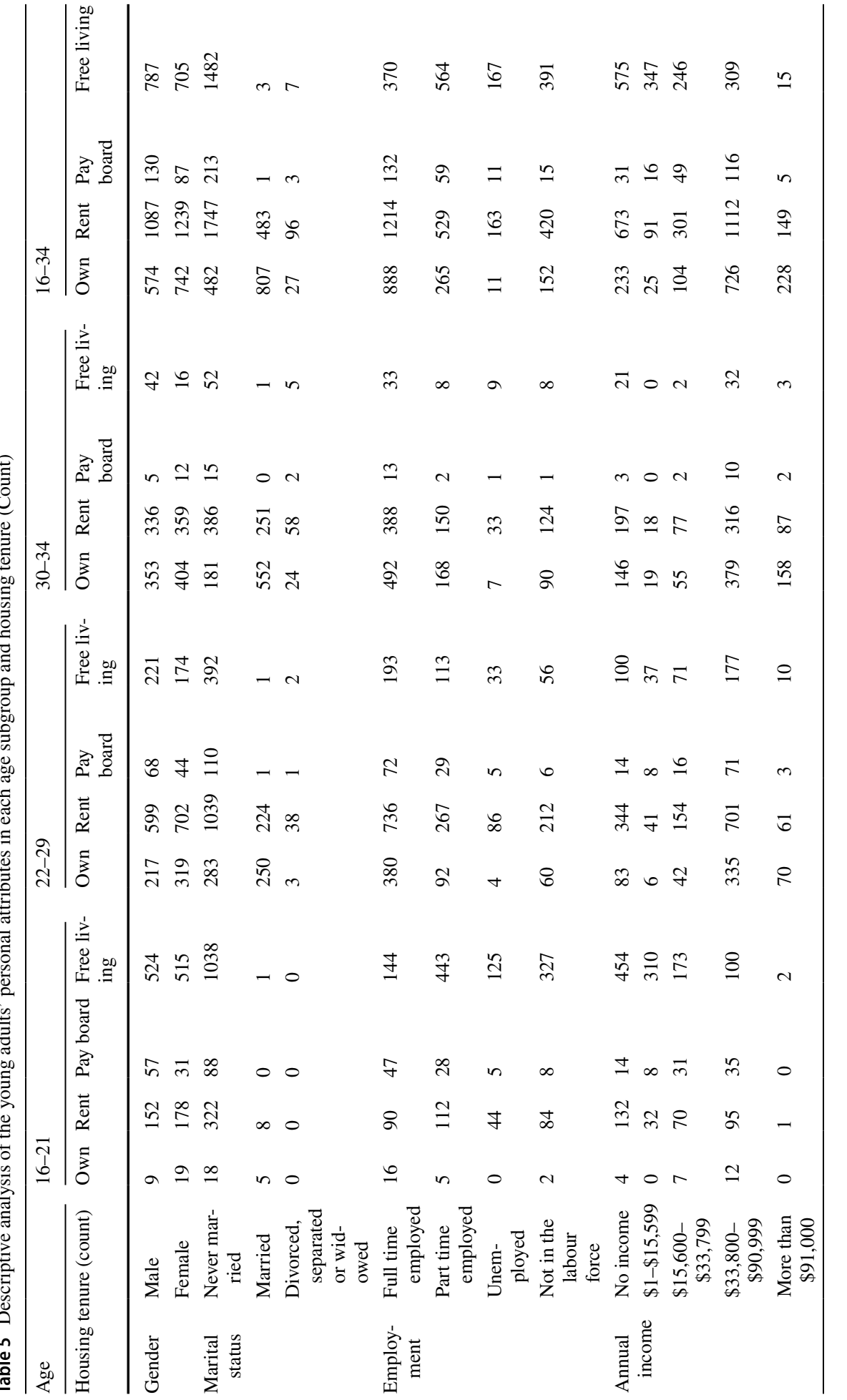




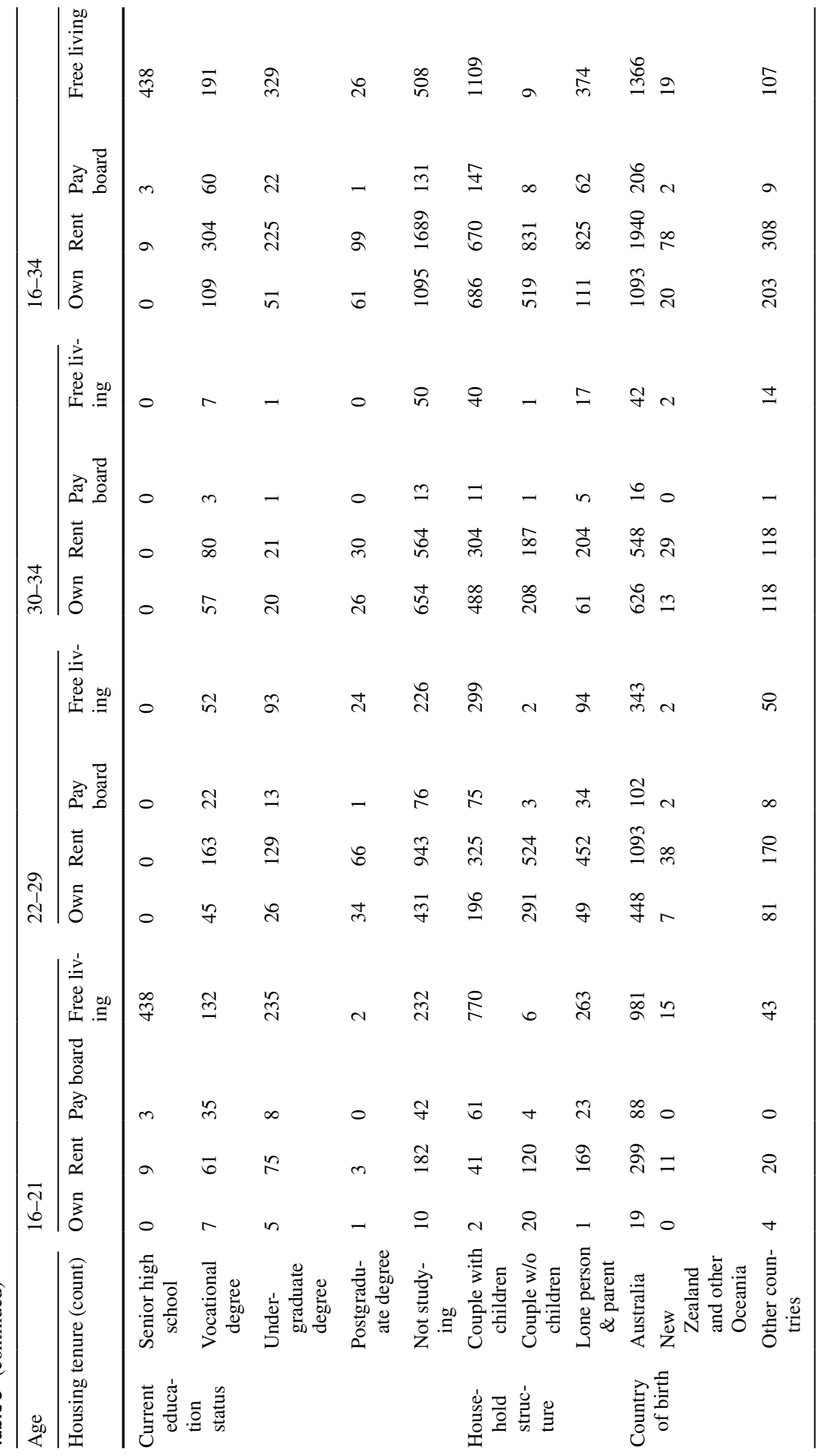


young adults in Australia appear to be more independent in their housing tenure choices as compared with men.

Among young adults 16-34 years old, married individuals mostly own their dwellings $(62.36 \%)$ and they prefer renting their houses $(37.33 \%)$ as a second option. Never married young adults choose either to rent the dwelling (44.52\%) or to live with parents for free $(37.77 \%)$. Divorced, separated or widowed young adults predominantly rent their dwellings (72.18\%). It appears that partly independent residence (paying board) and dependent residence (living with parents for free) are common tenure types for never-married young adults. Marriage has an influence on the residential independency, especially on home ownership decision, in the late years of young adulthood.

Young adults aged 16-34 years with full time jobs mainly prefer to rent $(46.62 \%)$ or own $(34.10 \%)$ a dwelling. $19.28 \%$ of full-time workers choose to live with their parents either for free (14.21\%) or pay board (5.07\%). The housing tenure choices among the parttime employed young adults are evenly distributed among renting (37.33\%) and live with parents for free $(39.80 \%)$. The remaining $18.70 \%$ own their houses and $4.16 \%$ pay board. Unemployed young adults mostly choose to live with parents for free $(47.44 \%)$ and to rent a dwelling (46.31\%) as a second common type of tenure. In their middle years of young adulthood, people prefer to rent a house as their first tenure choice independent of the employment status. Upon further investigation, it is observed that full-time workers own their houses, whereas part-time workers and unemployed young adults live with parents for free as anticipated. Mature young adults with full time (53.13\%) and part time (51.22\%) jobs have a preference to own their dwellings. As anticipated, a substantial part of unemployed mature young adults (18.00\%) lives with parents for free. Among all young adults, paying board seems to be chosen mainly by full time workers in early young adulthood and also by full/part time workers in their middle years of young adulthood.

Analysing the effect of annual income on young Australians' housing tenure choices, we observe that as the income level increases from $\$ 1-15,599$ to more than $\$ 91,000$, the ratio of homeowners notably increases from $5.22 \%$ to $57.43 \%$, and that the ratio of renters increases from $19.00 \%$ to $37.53 \%$. In the early young adulthood (16-21 years old), people with no income, as anticipated, dominantly live with parents for free (75.17\%). As the income level rises, they move to either pay board or rent a dwelling. In middle young adulthood, lower income groups mainly prefer to rent a house (44.57-54.42\%) and live with parents for free (25.09-40.22\%). In the late young adulthood, higher income groups dominantly prefer to own their dwelling. Evidently, annual income level has a positive effect on the home ownership decisions of young adults.

HILDA survey collects data on the current education status of all members of the interviewed households instead of the highest education degrees obtained. In this respect, it is observed that among those aged 16-34 years, the proportion of living with parents for free is remarkably high ( $97.33 \%$ for those studying in senior high school; $56.17 \%$ for those in vocational degree and $72.76 \%$ for those undertaking an undergraduate degree). Young people who study postgraduate degree prefer renting a house $(52.94 \%)$ as the first tenure and owning a house $(32.62 \%)$ as the second option. Living with parents for free $(28.77 \%)$ and pay board $(9.04 \%)$ seems to be mostly chosen by young adults who study vocational education and training courses. It is clear that paying board is very popular among those young adults aged 16-29 years, currently studying a vocational education.

Upon the investigation of the relationship between country of birth and housing tenure choices, young adults in their early young adulthood predominantly live with parents for free regardless of their country of birth. In the middle young adulthood, young adults prefer to rent their dwellings, again, irrespective of the country of birth. In this age sub-group 
of 22-29 years old, those born in Australia (5.14\%) and New Zealand \& other Oceania countries $(4.08 \%$ ) have partly independent residence (i.e., pay board while living with their parents). Amongst the mature young adults (aged 30-34 years old), owning a house is the most common type of housing tenure for those born in Australia, while renting is the dominant housing tenure type for young New Zealanders. Young people born overseas (outside of Australia, New Zealand \& other Oceania countries) do not have a clear preference for owning or renting a house.

In summary, 31.94\% of young Australians aged 16-34 live with parents; $27.88 \%$ live in parental home for free, and $4.06 \%$ pay board. As one would expect, young adults' co-residence with parents increases significantly among those aged between 16 and 21. Particularly, $76.15 \%$ of early young adults live with parents-while $70.20 \%$ live in their parental home for free, $5.95 \%$ pay board. The preliminary analysis results suggest that housing tenure choices of young Australians change with age. Young people prefer to live with parents for free in their early young adulthood (16-21 years old), rent their house in their middle young adulthood (22-29 years old), and become homeowners in their late young adulthood (30-34 years old). Partly independent young adults who live with parents and pay board are prominent in the early-to-middle years of young adulthood. Surprisingly, 42 (or 5.71\%) mature young men did not achieve residential independency and still live with parents for free.

\section{Multinomial logistic regression analysis: results and discussion}

This study uses multinomial logistic regression ${ }^{6}$ to study the four dependent housing tenure choices. Information on individual-level housing tenure is used to code each enumerated person as a homeowner (category 1), renter (category 2), living with parents and pay board (category 3), and living with parents under rent-free condition (category 4). Control variables are defined at the personal level, including age, gender, marital status, employment, annual income, current education status, family structure, and the country of birth.

Separate multinomial logistic regression models are drawn for different age categories of young adulthood. The first model demonstrates the regression analysis for the full sample of young adults in Australia to explain the relationship of the housing tenure choices of young adults aged between 16 and 34 years with reference to their personal characteristics. The two consecutive models focus on the middle young adulthood and mature young adulthood, respectively.

Employing the similar methodology as Coulter (2018) and Bayrakdar, et al. (2019), the model estimates are reported as average marginal effects (AMEs) from the multinomial models. The AMEs denote the change in probability, by changing only an independent variable (Coulter, 2018). Table 6 displays AMEs for each housing tenure in specific age category.

Regression result for the full sample of young adults aged 16-34 years reveals that the older people are, the more likely to own a house. Young Australians have a higher likelihood to become homeowner and less prone to live with parents for free in their middle and mature young adulthood (when aged 22-34) in comparison to their early years of young adulthood (aged 16-21). This positive association between age and home ownership

${ }^{6}$ Refer to Coulter (2018) and Long and Freese (2006) for similar regression analysis. 


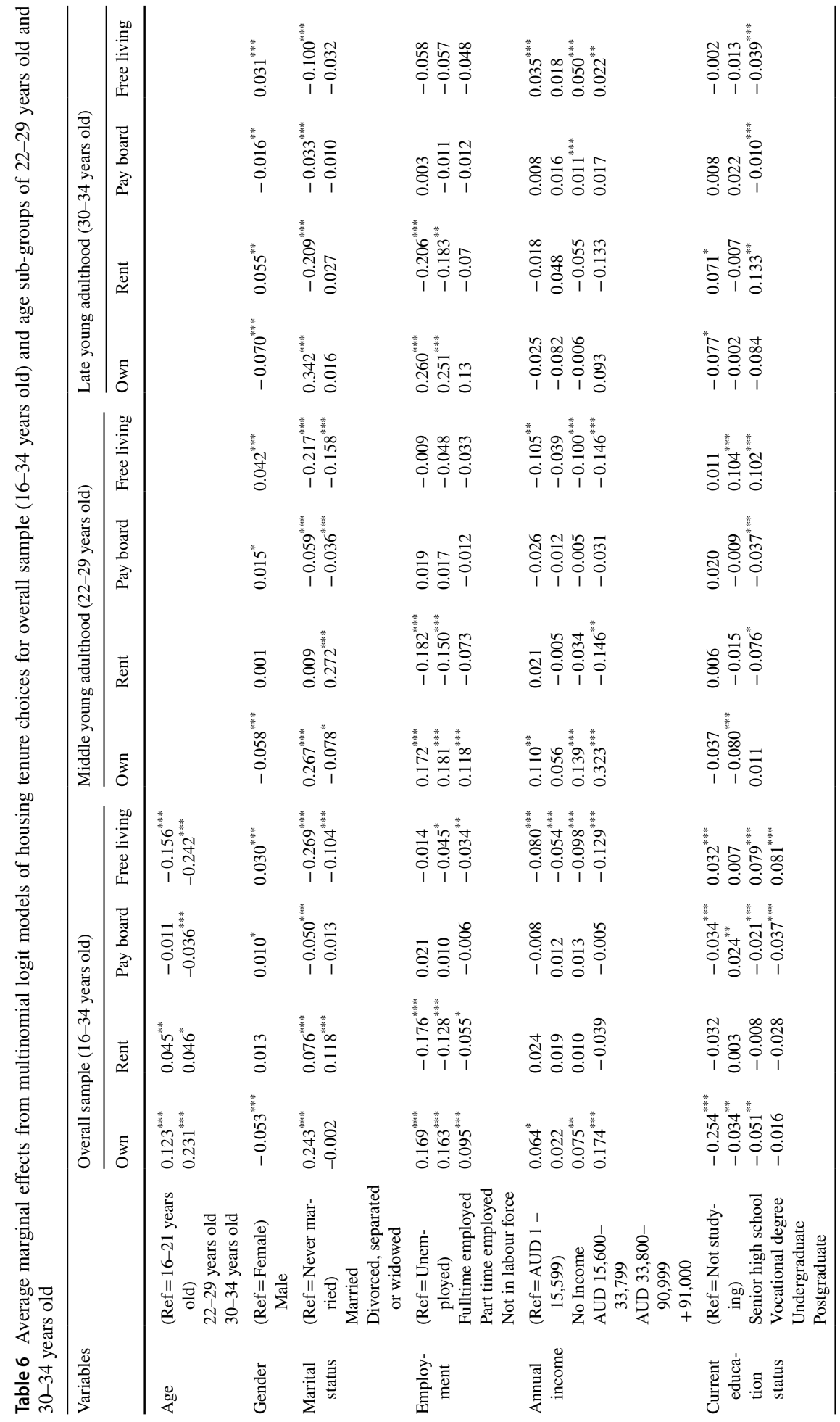




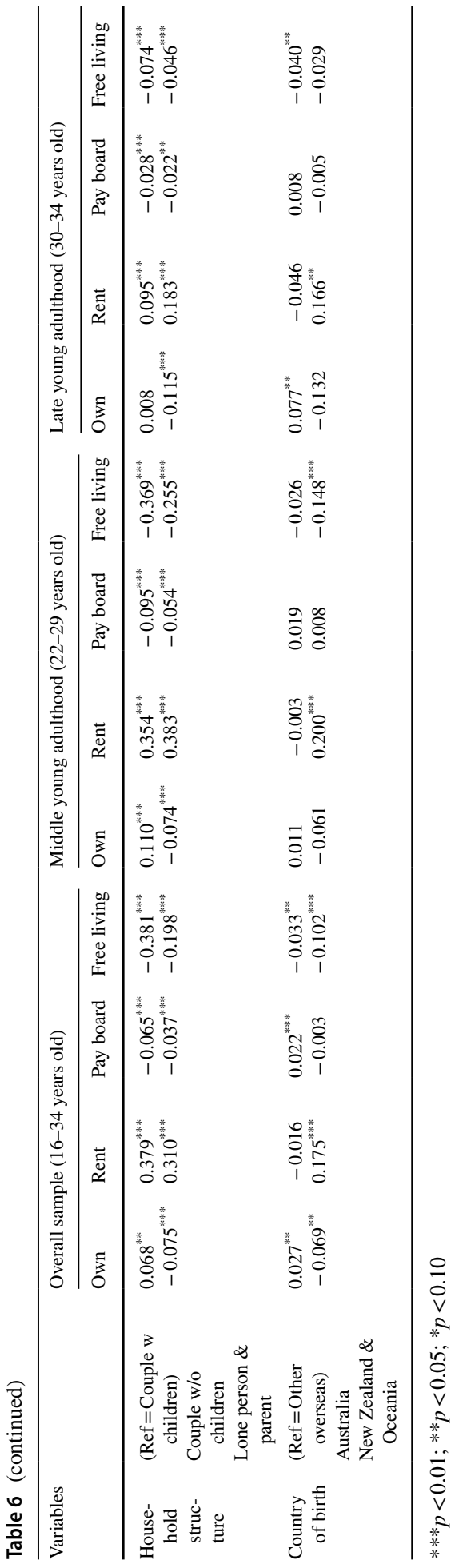


is noticeably stronger for mature young adults, or those aged 30-34. Age is an important factor affecting housing career especially in countries with more regulated or restricting lending practices, where people have to accumulate more savings to pay larger deposits (Blaauboer, 2010). Young people are still shaping their occupational careers and generally have shorter employment histories (Helderman \& Mulder, 2007) and mostly are employed on a part-time or short-term contract basis (Badcock \& Beer, 2000; Winter \& Stone, 1999), which makes owning a house harder. Evidently, the older people are, the more time they have had to achieve home ownership (Helderman \& Mulder, 2007).

Previous studies on the effect of gender on housing careers of young adults provided mixed findings. For example, Boehm and Schlottmann (1999) and Helderman and Mulder (2007) found that in comparison to men, women have a lower probability of becoming home owners, due to the perception that women are earning lower income as compared to men. On the contrary, Bayrakdar et al. (2019) found that women in Britain and Germany are more likely to enter home ownership than men, which is suspected that women are establishing partnerships at younger ages. Several studies have also shown that young women leave their parental home earlier than men do (Goldscheider \& DaVanzo, 1985; Ward et al., 1992). The results show that young women in Australia are more independent in their housing tenure choices in comparison to young men. Young male adults, especially in their middle young adulthood, have a higher probability to live with parents. The gender effect on owner-occupation is markedly stronger in later ages of young adulthood. As males move into their late young adulthood (30-34 years old), they become less likely to own a house in comparison to females as the predicted AME for owning a house is -0.070 .

Marital status appears to be an influential factor in young Australians' housing pathways. The AMEs for marital status suggest that being married is correlated with a higher probability of owning, and vice-versa, a lower probability of co-residence with parents in each age sub-group. This effect is noticeably stronger among mature young adults aged between 30 and 34 years. This finding supports evidence from previous European studies, which found that marriage encourages home ownership in Germany and some Southern European countries; while there are few differences between the effects of cohabitation and marriage in Sweden, Britain and the Netherlands (Lauster \& Fransson, 2006; Thomas \& Mulder, 2016). Baxter and McDonald (2005) argued that in Australia, legal marriage is the trigger to move into home ownership. Our results also reveal that never married young people are significantly more likely to live with parents for free and pay board when compared with the married and divorced/separated or widowed young adults. Hence, non-marriage (or late marriage) among young Australians increases the probability of living with parents, either for free or pay board. The predicted probability of renting is significantly higher for the divorced/separated or widowed young adults as compared with the married and never married young people, especially in middle young adulthood. One could possibly claim that relationship break-ups and divorces positively affect the probability of renting in the private housing market, especially for those aged 22-29 years. Never married young adults who previously have not experienced independent living prefer to live with parents; while the divorced/separated or widowed young adults who have already experienced their residential independency have a preference to maintain their independency by renting privately.

The AMEs for employment status indicate that young people with full and part-time jobs are more likely to own their dwellings and less likely to rent a dwelling relative to the unemployed. Unsurprisingly, people with secure jobs are more likely to both prefer and enter home ownership than those with little or no job security (Clark et al., 1997). The results show that, in general, employment status has weak and insignificant effects on the 
probability of parental co-residence-living parents for free and pay board-especially for those aged 22-34 years. Having a full-time job in the early young adulthood increases the probability of paying board but the estimated AMEs are statistically insignificant.

Income level is an important determining factor on housing tenure choice because of the increase in house prices. To secure a mortgage, a substantial down payment (or deposit) is often necessary. The long-term financial commitment has a negative impact on the decision for home ownership. The findings reveal that high income does not necessarily have a direct relationship to owning a house (Helderman \& Mulder, 2007). In the early-to-middle young adulthood, having a higher level of income (from AUD 33,800 to more than 91,000) increases the probability of owning a house. Surprisingly, being a mature young adult (aged 30-34 years) and having a higher level of income (AUD 33,800 to more than AUD 91,000) is associated with a higher probability of living with parents for free. Mature, high-earning young adults' motivation for living in parental house rent-free can be explained by the aim of saving money to buy a house or investment property (instead of spending his/her money on rent) and also care arrangements for their children or elderly parents (Jennings-Edquist, 2019).

Similarly, the level of education obtained are expected to correlate with the ease to attain home ownership. This phenomenon is true in Britain and the Netherlands while has no significant effect in Germany (Bayrakdar, et al., 2019; Helderman \& Mulder, 2007). Our findings suggest that young Australians studying in senior high school or university degrees (undergraduate/postgraduate) have a lower probability to own a house or pay board, and a higher probability of co-residing with parents. Studying a postgraduate degree, aged 30-34 increases the probability of renting and reduces the probability of parental co-residence. We also find that young adults in vocational education are partly independent as they are highly likely to live with parents and pay board (0.024).

The predicted probability of home ownership is significantly higher for native Australians as compared with overseas-born young population. The absolute effect of being native Australian on the probability of owner-occupation, shown by the AME, is much higher for young people aged 30 to 34 (0.077) than the full sample of young people from 16 to 34 years of age (0.027). Young adults born in Australia, New Zealand, and other Oceania countries are less likely to live with parents for free as compared to overseas-born young adults (e.g., in the USA, the European and Asian countries). In each age sub-group, those born in New Zealand and other Oceania countries (besides Australia) have a significantly higher probability of renting a dwelling as compared with the native Australians and those born overseas. Furthermore, being a native-born Australian and aged 16-21 significantly increases the probability of living with parents and paying board.

Examining the effect of household structure on housing tenure choice of young people reveal that that couple families (with or without children) have a higher probability to be homeowners, in comparison to one-person/one parent households. This result is consistent with previous findings as Mulder and Wagner (1998) argued that people in general do not enter into home ownership before they have formed a stable household and as Helderman and Mulder (2007) highlighted that parents with children are more responsive to the long-term commitments than one-person households. Furthermore, Clark et al. (1997) stated that dual earner couples are considerably more likely to become homeowners than single-earner couples as they can pool resources together. Our results also indicate that one person/one parent households and couples without children have a higher probability of renting a house. 


\section{Conclusion}

This study is the first attempt to unearth individual-level data from the household-level HILDA survey to study housing tenure choices of young Australians. In addition to owning, renting a house and living with parents for rent-free, the paper investigates a growing, novel type of housing tenure among young population, namely, living with parents and pay board. The results of preliminary data analysis reveal that almost $32 \%$ of young Australians aged 16-34 live with parents in 2017; while 27.9\% live in parental home for free, the remaining $4.1 \%$ pay board. Young adults, who are partly independent in their residential pathway and pay board to live with parents, are mainly in their early-to-middle years of young adulthood (16-29-year-olds) and largely study vocational courses.

Our regression results appear consistent with prior research and indicate that sociodemographic characteristics strongly affect young Australians' housing tenure choices. First, young women in Australia are more independent in their housing tenure choices (i.e., owning and renting a house) in comparison to young men, which is consistent with previous findings by Bayrakdar, et al. (2019) and Ward et al. (1992). Almost 6\% of mature young men, those aged 30-34, did not achieve residential independency and still live with parents for free. Second, age has a significant positive association with the probability of being a homeowner; young Australians, especially those aged 30-34, have a higher likelihood to become homeowner and less prone to live with parents for free. Blaauboer (2010), Helderman and Mulder (2007), Badcock and Beer (2000), and Winter and Stone (1999) have all reported the positive link between age and home ownership. Third, consistent with prior research by Helderman and Mulder (2007), we find that high income does not necessarily have a direct relationship to owning a house in each age group. Whilst being in the early-to-middle young adulthood and having higher level of income increases the probability of home ownership, mature young adults with high-income have unpredictably a higher likelihood to live with parents for free. Their motivation for living with parents rent-free can be explained by either saving money to buy a house or investment property or taking care of their elderly parents.

One of the most notable findings of this study is that marital status has a strong impact on housing tenure choices of young people in Australia. Non-marriage (or late marriage) among young Australians increases the probability of living with parents as never married young adults prefer to live with parents, either for free or pay board. Divorced, separated or widowed young adults, who already experienced their residential independency have a preference for maintaining their independency (i.e., renting privately), especially in their middle young adulthood (aged 22-29 years old). One could possibly claim that relationship break-ups and divorces positively affect the probability of renting in the private housing market. And, as anticipated, being married is correlated with a higher probability of owning a dwelling (i.e., Thomas \& Mulder, 2016; Lauster \& Fransson, 2006Baxter and McDonald, 2005) and a lower probability of co-residence with parents in each age subgroup. Another noteworthy finding is that young adults in vocational education are partly independent and highly likely to live with parents and pay board, while those studying in senior high school or university degrees have a lower probability to pay board or own a house, and a higher probability of co-residing with parents for free. Lastly, studying a postgraduate degree, aged 30-34 increases the probability of renting and reduces the probability of parental co-residence.

Regarding the country-of-origin effect on one's housing tenure choice, the results indicate that young adults born in Australia, New Zealand, and other Oceania countries are 
less likely to live with parents for free as compared to overseas-born young adults. Furthermore, being a native-born Australian and aged 16-21 significantly increases the probability of living with parents and paying board.

This research is definitely a steppingstone to future research. Using the same methodology to derive individual-level tenure choices from household-level, coupled with a longitudinal data analysis could definitely give a better picture on the housing career changes. The findings of this research give a greater understanding of young Australian's housing tenure choices, which could inform the change in the current housing policy. It is clear that the housing tenure choices of young people have moved from the conventional owners and renters, to a non-traditional forms of tenure choice-i.e., staying with parents for free and paying board. These creative forms of tenure choice give young adults more flexibility in managing their finance. To illustrate, staying with parents could speed up the saving progress for the down payment of a new house; renting from one property to another property gives them flexibility in choosing a location that is near to their workplace. Instead of addressing the question on 'how to increase owner occupation?', policy makers should be extending the benefits of owner occupation to a larger portion of the population (Bourassa et al., 1995). In helping young people in fulfilling the great 'Australian dream', the focus should be given to the independent (renters) and partly independent (living with parents and pay board) young adults to assist them in climbing up the housing career ladder, possibly through shared equity and co-operative schemes.

Open Access This article is licensed under a Creative Commons Attribution 4.0 International License, which permits use, sharing, adaptation, distribution and reproduction in any medium or format, as long as you give appropriate credit to the original author(s) and the source, provide a link to the Creative Commons licence, and indicate if changes were made. The images or other third party material in this article are included in the article's Creative Commons licence, unless indicated otherwise in a credit line to the material. If material is not included in the article's Creative Commons licence and your intended use is not permitted by statutory regulation or exceeds the permitted use, you will need to obtain permission directly from the copyright holder. To view a copy of this licence, visit http://creativecommons.org/licenses/by/4.0/.

\section{References}

Aassve, A., Cottini, E., \& Vitali, A. (2013). Youth prospects in a time of economic recession. Demographic Research, 29, 949-961.

Adamopoulou, E., \& Kaya, E. (2018). Young adults living with their parents and the influence of peers. Oxford Bulletin of Economics and Statistics, 80(3), 689-713.

Andrew, M. (2010). The changing route to owner occupation: The impact of student debt. Housing Studies, 25(1), 39-62.

Andrews, D., \& Sanchez, A. C. (2011). The evolution of homeownership rates in selected OECD countries: Demographic and public policy influences. OECD Journal: Economic Studies, 2011(1), 1-37.

Aranda, L. (2015). Doubling up: A gift or a shame? Intergenerational households and parental depression of older Europeans. Social Science \& Medicine, 134, 12-22.

Arnott, R. (1997). Economic theory and housing. In E. S. Mills (Ed.), Handbook of regional and urban economics (pp. 959-988). Elsevier Science Publishing.

Arundel, R., \& Doling, J. (2017). The end of mass homeownership? Changes in labour markets and housing tenure opportunities across Europe. Journal of Housing and the Built Environment, 32(4), 649-672.

Arundel, R., \& Lennartz, C. (2017). Returning to the parental home: Boomerang moves of younger adults and the welfare regime context. Journal of European Social Policy, 27(3), 276-294.

Arundel, R., \& Ronald, R. (2016). Parental co-residence, shared living and emerging adulthood in Europe: Semi-dependent housing across welfare regime and housing system contexts. Journal of Youth Studies, 19(7), 885-905. 
Australian Bureau of Statistics. (2010). 1370.0 - Measures of Australia's progress, 2010 Retrieved 23 October 2019. https://www.abs.gov.au/ausstats/abs@.nsf/Lookup/by\%20Subject/1370.0 2010 Chapt er Family $\% 20$ structure $\% 20(4.5 .6 .1)$

Badcock, B., \& Beer, A. (2000). Home truths: Home ownership and housing wealth in Australia. Melbourne University Press.

Baum, S., \& Wulff, M. (2002). Housing aspirations of young Australians: Variations on a dream. Real Estate Institute of Queensland (REIQ) Journal, 10-12.

Bayrakdar, S., Coulter, R., Lersch, P., \& Vidal, S. (2019). Family formation, parental background and young adults' first entry into homeownership in Britain and Germany. Housing Studies, 34(6), 974-996.

Beck, U., \& Beck-Gernsheim, E. (2002). A life of one's own in a runaway world: Individualization, globalization and politics. In: Individualization: Institutionalized individualism and its social and political consequences.

Beer, A., \& Faulkner, D. (2009). 21st century housing careers and Australia's housing future: Australian Housing and Urban Research Institute.

Berngruber, A. (2015). 'Generation boomerang'in Germany? Returning to the parental home in young adulthood. Journal of Youth Studies, 18(10), 1274-1290.

Bessant, J. C., \& Johnson, G. (2013). "Dream on": Declining homeownership among young people in Australia? Housing, Theory and Society, 30(2), 177-192.

Billari, F. C., \& Liefbroer, A. C. (2007). Should I stay or should I go? The impact of age norms on leaving home. Demography, 44(1), 181-198.

Blaauboer, M. (2010). Family background, individual resources and the homeownership of couples and singles. Housing Studies, 25(4), 441-461.

Boehm, T. P., \& Schlottmann, A. M. (1999). Does home ownership by parents have an economic impact on their children? Journal of Housing Economics, 8(3), 217-232.

Boterman, W. R., \& Van Gent, W. P. (2014). Housing liberalisation and gentrification: The social effects of tenure conversions in Amsterdam. Tijdschrift Voor Economische En Sociale Geografie, 105(2), 140-160.

Bourassa, S. C., Greig, A. W., \& Troy, P. N. (1995). The limits of housing policy: Home ownership in Australia. Housing Studies, 10(1), 83-104.

Bourassa, S. C. \& Yin, M. (2006) Housing tenure choice in Australia and the United States: Impacts of alternative subsidy policies. Real Estate Economics, 34(2), 303-328.

Burke, T., Pinnegar, S., Phibbs, P., Neske, C., Gabriel, M., Ralston, L., \& Ruming, K. J. (2007). Experiencing the housing affordability problem: Blocked aspirations, trade-offs and financial hardships. Australian Housing Research Institute.

Case, K. E. \& Shiller, R.J. (1988). The Behavior of home buyers in boom and post-boom markets. New England Economic Review (November/December), pp. 29-46.

Choi, J. H., Zhu, J., \& Goodman, L. (2018). Intergenerational homeownership: The impact of parental homeownership and wealth on young adults' tenure choices. Urban Institute.

Cigdem, M., \& Whelan, S. (2017). Intergenerational transfers and housing tenure-Australian evidence. International Journal of Housing Policy, 17(2), 227-248.

Clark, W. A. V., Deurloo, M. C., \& Dieleman, F. D. (1997). Entry to home-ownership in Germany: Some comparisons with the United States. Urban Studies, 34(1), 7-19.

Colic-Peisker, V., \& Johnson, G. (2012). Liquid life, solid homes: Young people, class and homeownership in Australia. Sociology, 46(4), 728-743.

Colic-Peisker, V., \& Johnson, G. (2010). Security and anxiety of homeownership: Perceptions of middleclass Australians at different stages of their housing careers. Housing, Theory and Society, 27(4), 351-371.

Commonwealth of Australia. (2019). Australian education system. Retrieved 11 October 2019, from https:// www.studyinaustralia.gov.au/english/australian-education/education-system

Cooper, D., \& Luengo-Prado, M. J. (2018). Household formation over time: Evidence from two cohorts of young adults. Journal of Housing Economics, 41, 106-123.

Coulter, R. (2018). Parental background and housing outcomes in young adulthood. Housing Studies, 33(2), 201-223.

Coulter, R., Ham, M. V., \& Findlay, A. M. (2016). Re-thinking residential mobility: Linking lives through time and space. Progress in Human Geography, 40(3), 352-374.

Daley, J., \& Coates, B. (2018). Housing affordability: Re-imagining the Australian dream. Australia.

Dettling, L. J., \& Hsu, J. W. (2018). Returning to the nest: Debt and parental co-residence among young adults. Labour Economics, 54, 225-236.

Druta, O., \& Ronald, R. (2018). Intergenerational support for autonomous living in a post-socialist housing market: Homes, meanings and practices. Housing Studies, 33(2), 299-316. 
Filandri, M., \& Bertolini, S. (2016). Young people and home ownership in Europe. International Journal of Housing Policy, 16(2), 144-164.

Fisher, J. D., \& Gervais, M. (2011). Why has home ownership fallen among the young? International Economic Review, 52(3), 883-912.

Flatau, P., James, I., Watson, R., Wood, G., \& Hendershott, P. H. (2003). Leaving the parental home in Australia over the 20th century: Evidence from the household income and labour dynamics in Australia (HILDA) Survey. In: HILDA conference (Vol. 13).

Forrest, R., \& Yip, N.-M. (2012). Young people and housing: Transitions, trajectories and generational fractures. Routledge.

Fuster, N., Arundel, R., \& Susino, J. (2019). From a culture of homeownership to generation rent: Housing discourses of young adults in Spain. Journal of Youth Studies, 22(5), 585-603.

Goldscheider, F. K., \& DaVanzo, J. (1985). Living arrangements and the transition to adulthood. Demography, 22(4), 545-563.

Goodman, A. C. (1990). Demographics of individual housing demand. Regional Science and Urban Economics, 20, 83-102.

Hall, A. (2017). Trends in home ownership in Australia: A quick guide.

Hamilton, C. (2008). The freedom paradox: Towards a post-secular ethics. Allen \& Unwin.

Heath, S., \& Calvert, E. (2013). Gifts, loans and intergenerational support for young adults. Sociology, 47(6), 1120-1135.

Helderman, A., \& Mulder, C. (2007). Intergenerational transmission of homeownership: The roles of gifts and continuities in housing market characteristics. Urban Studies, 44(2), 231-247.

Henretta, J. C. (1987). Family transitions, housing market context, and first home purchase by young married households. Social Forces, 66(2), 520-536.

Holdsworth, C. (2004). Family support during the transition out of the parental home in Britain Spain and Norway. Sociology, 38(5), 909-926.

Hoolachan, J., McKee, K., Moore, T., \& Soaita, A. M. (2017). 'Generation rent' and the ability to 'settle down': Economic and geographical variation in young people's housing transitions. Journal of Youth Studies, 20(1), 63-78.

Houle, J. N., \& Warner, C. (2017). Into the red and back to the nest? Student debt, college completion, and returning to the parental home among young adults. Sociology of Education, 90(1), 89-108.

Hubert, F. (2007). The economic theory of housing tenure choice. In R. J. Arnott \& D. P. McMillen (Eds.), A companion to Urban economics (pp. 145-158). Blackwell.

Hughes, J. W. (1996). Economic shifts and the changing homeownership trajectory. Housing Policy Debate, 7(2), 293-325.

Jennings-Edquist, G. (2019). Multi-generational living: Why young Aussies are moving back home or not leaving, $A B C$ Life. Retrieved from https://www.abc.net.au/life/multi-generational-living-whyaussies-are-leaving-home-later/10089120

Kaplan, G. (2009). Boomerang kids: Labor market dynamics and moving back home. Paper presented at Federal Reserve Bank of Minneapolis (Working Paper 675).

Lane, I. (2019). Death of the great Australian dream? Housing affordability a top concern, poll finds, The New Daily.

Lauster, N. T., \& Fransson, U. (2006). Of marriages and mortgages: The second demographic transition and the relationship between marriage and homeownership in Sweden. Housing Studies, 21(6), 909-927.

Le Blanc, D., \& Wolff, F.-C. (2006). Leaving home in Europe: The role of parents' and children's incomes. Review of Economics of the Household, 4(1), 53-73.

Lennartz, C., Arundel, R., \& Ronald, R. (2016). Younger adults and homeownership in Europe through the global financial crisis. Population, Space and Place, 22(8), 823-835.

Long, J. S., \& Freese, J. (2006). Regression models for categorical dependent variables using Stata. Stata press.

McDonald, P. (2003). Changing home ownership rates in Australia: issues of measurement and interpretation. Australian Housing and Urban Research Institute.

McDonald, P., \& Baxter, J. (2005). Home ownership among young people in Australia: In decline or just delayed? Australian Journal of Social Issues, 40(4), 471.

McKee, K. (2012). Young people, homeownership and future welfare. Housing Studies, 27(6), 853-862.

Meen, G. (1998). Modelling Sustainable home-ownership: Demographics or economics? Urban Studies, 35(11), 1919-1934.

Medibank Private (2019). https://www.medibank.com.au/livebetter/my-medibank/healthcare/do-i-needh ealth-insurance-in-my-20s/.

Morris, E. W., \& Winter, M. (1978). Housing, family, and society. Wiley. 
Mudd, W., Tesfaghiorghis, H., \& Bray, J. R. (2001). Some issues in home ownership: Department of Family and Community Services Canberra.

Mulder, C. H., \& Billari, F. C. (2010). Homeownership regimes and low fertility. Housing Studies, 25(4), 527-541.

Mulder, C. H., Dewilde, C., van Duijn, M., \& Smits, A. (2015). The association between parents' and adult children's homeownership: A comparative analysis. European Journal of Population, 31(5), 495-527.

Mulder, C. H., \& Wagner, M. (1998). First-time home-ownership in the family life course: a West German-Dutch comparison. Urban Studies, 35(4), 687-713.

Mulder, C. H., \& Wagner, M. (2001). The connections between family formation and first-time home ownership in the context of West Germany and the Netherlands. European Journal of Population/ revue Europeenne De Demographie, 17(2), 137-164.

Mykyta, L., \& Macartney, S. (2011). The effects of recession on household composition: 'Doubling up'and economic well-being. Paper presented at Population Association of America Annual Meetings, Washington, D.C.

Öst, C. E. (2012). Housing and children: Simultaneous decisions? - a cohort study of young adults' housing and family formation decision. Journal of Population Economics, 25(1), 349-366.

Parkinson, S., Rowley, S., Stone, W., James, A., Spinney, A., \& Reynolds, M. (2019). Young Australians and the housing aspirations gap. Australian Housing and Urban Research Institute.

Percival, R. (1998). Changing housing expenditure, tenure trends and household incomes in Australia, 1975-76 to 1997: National Centre for Social and Economic Modelling, Universitiy of Canberra.

Reich, R. (2008). Supercapitalism. The transformation of business, democracy and everyday life. Society and Business Review., 50(2), 30.

Reilly, N. (2017) Why it's important that adult children living at home pay board, [Domain]:https://www. domain.com.au/living/why-its-important-that-adult-children-living-at-home-pay-board-20170 523-gw8nbe/.

Rodrigues, M. (2003). First home buyers in Australia. Economic Roundup, 4, 1-16.

Ronald, R. (2018). 'Generation rent' and intergenerational relations in the era of housing financialisation. Critical Housing Analysis, 5(2), 14.

Russell, D., \& Taylor, J. (2009). Living alone and depressive symptoms: The influence of gender, physical disability, and social support among hispanic and non-hispanic older adults. The Journals of Gerontology: Series B, 64B(1), 95-104.

Settersten, R. A. (2007). Passages to adulthood: Linking demographic change and human development. European Journal of Population, 23(3), 251-272.

Silverstein, M., Cong, Z., \& Li, S. (2006). Intergenerational transfers and living arrangements of older people in rural China: Consequences for psychological well-being. The Journals of Gerontology Series B: Psychological Sciences and Social Sciences, 61(5), S256-S266.

Thomas, M. J., \& Mulder, C. H. (2016). Partnership patterns and homeownership: A cross-country comparison of Germany, the Netherlands and the United Kingdom. Housing Studies, 31(8), 935-963.

Tosi, M., \& Grundy, E. (2018). Returns home by children and changes in parents' well-being in Europe. Social Science \& Medicine, 200, 99-106.

Ward, R., Logan, J., \& Spitze, G. (1992). The influence of parent and child needs on coresidence in middle and later life. Journal of Marriage and the Family, 54, 209-221.

Winter, I., \& Stone, W. (1999). Home ownership: Off course? In J. Yates \& M. Wulff (Eds.), Australia's housing choices. University of Queensland Press.

Winter, I. C., \& Stone, W. (1998). Social polarisation and housing careers: exploring the interrelationship of labour and housing markets in Australia. Australian Institute of Family Studies Melbourne.

Wood, G. A., \& Ong, R. (2017). The Australian housing system: A quiet revolution? Australian Economic Review, 50(2), 197-204.

Yates, J. (1999). Decomposing Australia's home ownership trends, 1975-1994. In: Australia's housing choices: University of Queensland Press for Australian Housing and Urban Research.

Yates, J. (2000). Is Australia's home-ownership rate really stable? An examination of change between 1975 and 1994. Urban Studies, 37(2), 319-342.

Yates, J. (2003). 'The more things change?' An overview of Australia's recent home ownership policies. European Journal of Housing Policy, 3(1), 1-33.

Youth Law Australia (2019). https://yla.org.au/qld/topics/at-home-parents-and-family/renting/ and https:// yla.org.au/act/topics/at-home-parents-and-family/renting/.

Publisher's Note Springer Nature remains neutral with regard to jurisdictional claims in published maps and institutional affiliations. 